\title{
The Suitability of Building Permit Proposal and Implementation in Kecamatan Makale Kabupaten Tana Toraja
}

\author{
Risliana Panggoa ${ }^{1}$
}

\begin{abstract}
The development of a city is always influenced by the activities of the community which required land for the activities to take place. Limited land availability demanded a sound control mechanism to ensure the sustainability of the economic growth. The general society has not yet fully understood Building Permit (Izin Mendirikan Bangunan - IMB) as the instrument of control of spatial use, resulting in mismatches between the actual building and the one proposed in the IMB. This research aimed to find the factors driving the mismatches in the IMB implementation within the local Makale community's understanding to concept of IMB. The study employed quantitative descriptive methods using frequency distribution tables and factor analysis. Factor analysis showed how lack of understanding and awareness in the concept of IMB, together with poor policy and execution by the local government have prevented the fully implementation. Some of the violations found included total building area, building function, Basic Structural Coefficient (Koefisien Dasar Bangunan - KDB), Building Line (Garis Sempadan Bangunan - GSB), and River Line (Garis Sempadan Sungai - GSS). The study concluded the need for IMB awareness promotion through socialization along with the technical procedures, enhancement of IMB monitoring and evaluation processes, finalization of IMB as regional regulation, and enforcement.
\end{abstract}

Keywords: city development, land use control, IMB, law enforcement

\section{PENDAHULUAN}

Dalam Undang-Undang No. 26 tahun 2007 tentang Penataan Ruang dan Peraturan Pemerintah No.15 Tahun 2010 tentang Penyelenggaraan Penataan Ruang, tertulis Pengendalian Pemanfaatan Ruang adalah sebagai bentuk dari upaya untuk menciptakan tertib tata ruang. Untuk tercapainya konsistensi pemanfaatan ruang dengan rencana tata ruang yang ditetapkan maka diperlukan pengendalian pemanfaatan ruang melalui perizinan disamping peraturan zonasi, pemberian insentif dan disinsentif, serta penanganan sanksi. Mekanisme perizinan yaitu usaha pengendalian melalui penerapan prosedur dan ketentuan yang ketat yang harus dipenuhi untuk menyelenggarakan suatu pemanfaatan ruang. Salah satu bentuk perizinan yang dimaksud adalah Izin Mendirikan Bangunan. Sebagai bentuk perizinan terutama dalam hal perizinan bangunan, Izin Mendirikan Bangunan (IMB) berkedudukan sebagai pengendali penggunaan lahan dalam perwujudan rencana kota.

Kabupaten Tana Toraja merupakan salah satu kabupaten di Provinsi Sulawesi Selatan dengan sumber daya alam yang cukup potensial untuk dikembangkan, bahkan Tana Toraja ditetapkan sebagai Kawasan Strategis Nasional dengan Sudut Kepentingan Sosial Budaya yang tertuang dalam lampiran X Peraturan Pemerintah No 26 tahun 2008. Budaya unik dan alam yang dimiliki oleh Tana Toraja telah menjadikannya sebagai salah satu tempat tujuan wisata yang sangat diminati oleh para wisatawan khususnya wisatawan mancanegara. Pada awalnya Kabupaten

\footnotetext{
${ }^{1}$ Risliana Panggoa adalah Staf Dinas Pekerjaan Umum Tata Ruang Kabupaten Tana Toraja, Sulawesi Selatan 
Tana Toraja merupakan satu kesatuan wilayah administrasi dengan Kabupaten Toraja Utara. Seiring dengan perkembangan Kecamatan Makale sebagai pusat aktivitas, maka harga lahan semakin meningkat sehingga masyarakat semakin sulit untuk mengakses lahan. Akibatnya masyarakat berusaha untuk memaksimalkan penggunaan lahan mereka tanpa memperhatikan lagi lahan terbuka hijau serta Garis Sempadan Bangunan (GSB). Kondisi tersebut dapat ditemukan di sekitar pusat Kecamatan Makale dimana masyarakat membangun di sepanjang jalan tanpa memperhatikan GSB yang telah ditetapkan dalam Perda No.11 Tahun 2002 yang kemudian diubah menjadi Perda No.3 Tahun 2009 tentang Retribusi Izin Mendirikan Bangunan. Demikian halnya area sepanjang sungai Ariang, masyarakat bahkan membangun permukiman di bantaran sungai tanpa memperdulikan Garis Sempadan Sungai. Mereka tidak menyadari bahwa daerah sepanjang sungai sangat rawan bencana banjir bandang terutama pada musim hujan. Meskipun banjir sudah beberapa kali terjadi, namun masyarakat tetap mempertahankan permukiman di daerah tersebut.

Masyarakat dalam mengimplementasikan IMB tidak sepenuhnya mematuhi peraturan tersebut. Masih terjadi pelanggaran/ketidaksesuaian dalam pelaksanaan IMB terutama dalam persyaratan teknis yaitu luas bangunan, fungsi bangunan, jenis bangunan, Koefisien Dasar Bangunan, Koefisien Lantai Bangunan, Garis sempadan Bangunan/Garis sempadan Sungai. Persyaratan teknis yang tercantum dalam pengajuan IMB masyarakat tidak sesuai dengan realisasi di lapangan. Pelanggaran IMB yang terjadi dalam masyarakat tidak merupakan suatu masalah penting bagi pemerintah daerah setempat. Hal ini dapat dilihat dengan tetap disetujuinya dan dikeluarkannya Izin Mendirikan Bangunan padahal bangunan yang diajukan untuk IMB melanggar ketentuan seperti yang tercantum dalam Perda tentang IMB. Suatu realita yang akan semakin memicu masyarakat untuk melakukan pelanggaran terhadap pelaksanaan IMB karena pemerintah tidak menindak tegas setiap pelanggaran yang terjadi terhadap pelaksanaan IMB. Melihat kondisi pelaksanaan IMB di Kecamatan Makale yang belum optimal dengan segala permasalahannya, maka penyusun tertarik untuk melakukan pengkajian/penelitian mengenai faktor-faktor apa yang mempengaruhi terjadinya kesesuaian pengajuan dan pelaksanaan IMB di Kecamatan Makale dalam konteks pemahaman masyarakat terhadap peraturan IMB yang berlaku di lokasi penelitian.

Secara geografis Kecamatan Makale dikelilingi oleh perbukitan sehingga memiliki tingkat kelerengan yang tinggi. Dengan kondisi alam tersebut banyak ditemui masyarakat yang mendirikan bangunannya di lokasi yang curam dan rawan bencana longsor. Salah satu faktor penyebabnya adalah karena masyarakat tidak punya pilihan lokasi lain untuk membangun. Demikian halnya dalam pemanfaatan lahan, dengan hak kepemilikan lahan yang dimiliki oleh masyarakat memunculkan pemahaman di tengah masyarakat bahwa mereka punya hak untuk memfungsikan lahan yang mereka miliki. Alhasil masyarakat berusaha memaksimalkan pemanfaatan lahan mereka terutama yang memiliki lahan terbatas. Hal ini salah satu penyebab masyarakat kurang peduli dengan aturan penataan ruang khususnya tentang IMB. IMB sebagai instrumen pengendalian pemanfaatan ruang tidak berfungsi sebagaimana mestinya, dalam artian masih terjadinya pelanggaran terhadap pelaksanaan IMB di Kabupaten Tana Toraja terutama di Kecamatan Makale sebagai ibukota kabupaten. Masyarakat yang mengajukan IMB belum bisa mematuhi secara utuh ketentuan teknis yang telah ditetapkan dalam Perda tentang IMB.

Bentuk pelanggaran atau kesesuaian pengajuan dan pelaksanaan IMB yang terjadi di Kecamatan Makale yaitu ketidaksesuaian terhadap Prosedur IMB, ketidaksesuaian terhadap Garis Sempadan (GSB dan GSS), Koefisien Dasar Bangunan (KDB), fungsi bangunan, jenis bangunan, dan luas bangunan. Permasalahan utama pada lokasi penelitian adalah masih 
terjadinya ketidaksesuaian antara pengajuan IMB dengan kondisi eksisting bangunan masyarakat dan kurangnya pemahaman masyarakat tentang peraturan IMB, sehingga perlu mendapat perhatian khusus dari pihak pemerintah. Dengan demikian perlunya peningkatan kesadaran dan pemahaman masyarakat akan pentingnya pelaksanaan IMB tersebut mengingat IMB adalah salah satu instrumen pengendalian pemanfaatan ruang agar dapat membawa perkembangan kota lebih teratur dan terarah. Oleh karena itu, tujuan dari penelitian ini adalah untuk mengetahui faktor-faktor apa yang mempengaruhi ketidaksesuaian/pelanggaran dalam pelaksanaan IMB di Kecamatan Makale Kabupaten Tana Toraja. Dengan sasaran yang ingin dicapai adalah mengidentifikasi karakteristik masyarakat dan bangunan pemohon IMB pada wilayah penelitian, menganalisis pemahaman masyarakat terhadap peraturan IMB, menganalisis ketidaksesuaian pengajuan IMB dengan kondisi bangunan saat ini, menganalisis faktor-faktor yang mempengaruhi ketidaksesuaian/pelanggaran dalam pelaksanaan peraturan IMB.

\section{METODE PENELITIAN}

Pendekatan yang digunakan adalah pendekatan kuantitatif. Strategi penelitian yang digunakan adalah penelitian survei dengan memaparkan karakteristik, pemahaman masyarakat dan kesesuaian pengajuan dan pelaksanaan IMB sehingga akan diketahui faktor-faktor yang mempengaruhi ketidaksesuaian pelaksanaan Izin Mendirikan Bangunan di Kecamatan Makale Kabupaten Tana Toraja, dengan penyebaran kuesioner dalam pengumpulan data sehingga populasi dapat tergeneralisasi berdasarkan sampel yang telah ditentukan sebelumnya. Populasi dalam sampel ini adalah bangunan dan seluruh warga masyarakat yang mengajukan pengajuan IMB yang terdiri dari bangunan permanen dan semi permanen, serta surat izin mendirikan bangunan yang telah dikeluarkan dalam kurun waktu 5 tahun dari tahun 2006-2010 di 5 kelurahan (Kelurahan Bombongan, Kelurahan Tondon Mamullu, Kelurahan Buntu Burake, Kelurahan Kamali Pentalluan, dan Kelurahan Pantan) di Kecamatan Makale. Adapun Surat Izin Mendirikan Bangunan yang telah dikeluarkan di kelurahan tersebut adalah sebanyak 313 Pengajuan Izin Mendirikan Bangunan. Teknik sampling yang digunakan dalam penelitian ini adalah teknik sampling secara stratified proportional cluster sampling. Teknik analisis yang digunakan adalah analisis deskriptif kuantitatif dan analisis faktor.

\section{GAMBARAN UMUM WILAYAH STUDI}

Ruang lingkup spasial makro penelitian ini adalah Kecamatan Makale sebagai Ibukota Kabupaten Tana Toraja yang terdiri atas 14 (empat belas) kelurahan dan 1 (satu) lembang. Pemilihan Kecamatan Makale sebagai lokasi penelitian ini didasarkan atas beberapa alasan yaitu Kecamatan Makale sebagai Ibukota Kabupaten Tana Toraja dengan pertumbuhan penduduk yang cukup tinggi dan sebagai pusat kegiatan di Kabupaten Tana Toraja baik pusat ekonomi, pemerintahan, dan kegiatan pendidikan. Sebagai ibukota kabupaten maka Kecamatan Makale membutuhkan pembangunan sarana dan prasarana sebagai upaya untuk menunjang aktivitas yang berlangsung dalam wilayah Kabupaten Tana Toraja. Sejak beberapa tahun terakhir, pemerintah melaksanakan pembangunan di seluruh wilayah Kabupaten Tana Toraja utamanya pembangunan infrastruktur jalan sebagai upaya peningkatan jangkauan ke wilayah-wilayah yang belum dapat terjangkau namun memiliki potensi sumber daya alam yang dapat dikembangkan pemanfaatannya. Secara khusus dalam menunjang fungsi Kecamatan Makale, maka dilaksanakan pembangunan sarana dan prasarana seperti pembangunan perkantoran, fasilitas Puskesmas, fasilitas pendidikan, dan sarana infrastruktur jalan yang terus 
ditingkatkan. Masyarakat juga ikut menyemarakkan perkembangan Kecamatan Makale dengan terjadinya peningkatan pembangunan rumah tinggal dan bangunan lainnya. Hal ini dapat dilihat dari jumlah permohonan IMB yang terus meningkat dari tahun ke tahun.

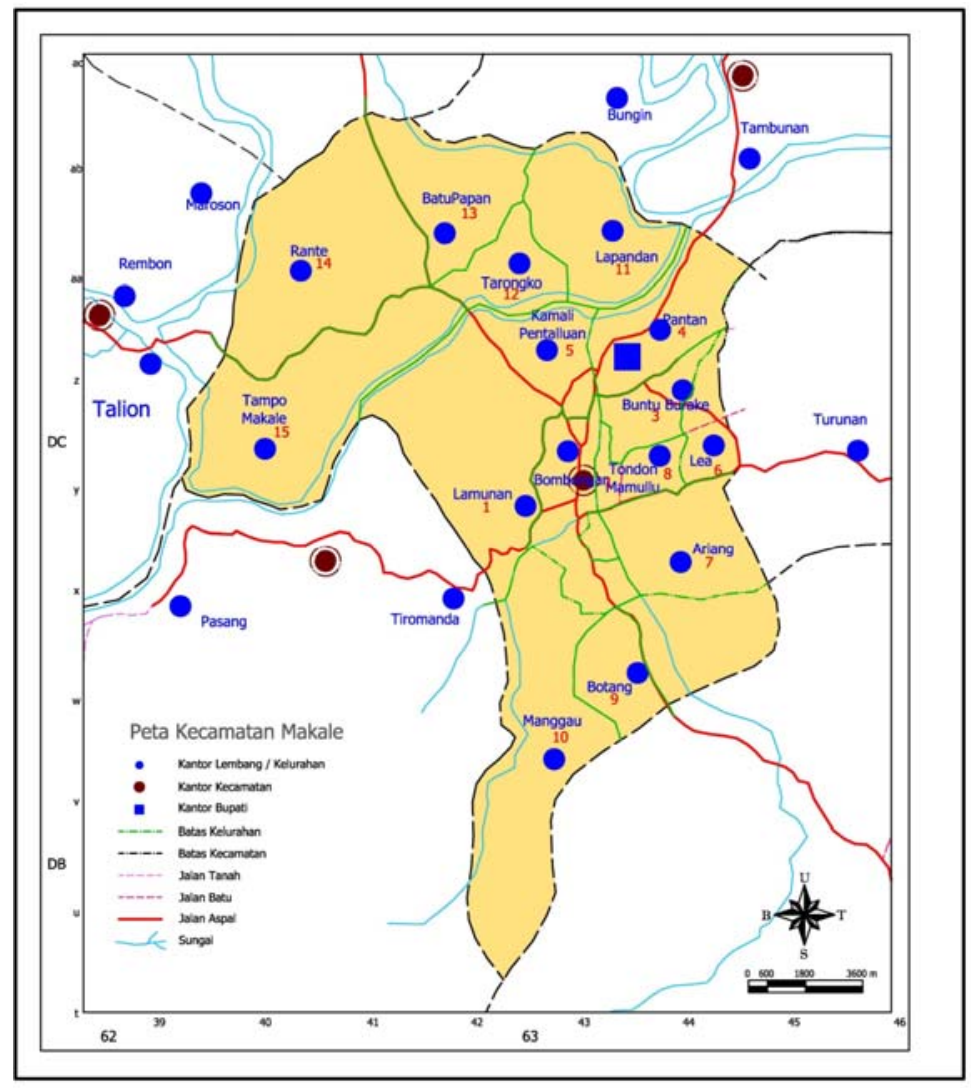

Sumber: Dinas Permukiman Dan Tata Ruang, 2011

GAMBAR 1

PETA KECAMATAN MAKALE

\section{PEMAHAMAN HUKUM DAN PELAKSANAANNYA}

Hukum adalah alat atau sarana untuk mengatur dan menjaga ketertiban guna mencapai suatu masyarakat yang berkeadilan dalam menyelenggarakan kesejahteraan sosial yang berupa peraturan-peraturan yang bersifat memaksa dan memberikan sanksi bagi yang melanggarnya, baik itu untuk mengatur masyarakat ataupun aparat pemerintah sebagai penguasa. (Muchsin, 2002:19). Pengertian hukum menurut Victor Hugo adalah kebenaran dan keadilan, sedangkan Prof.MR.E.K.Meyers berpendapat bahwa hukum adalah keseluruhan norma-norma dan penilaian-penilaian tentang harga susila yang mempunyai hubungan dengan perbuatanperbuatan manusia sebagai anggota masyarakat. Wiener dalam Rasjidi (1993:94) mendefinisikan hukum sebagai suatu sistem pengawasan perilaku (ethical control) yang diterapkan terhadap sistem komunikasi. Wujud hukum adalah norma dan norma itu merupakan produk dari suatu pusat kekuasaan yang memiliki kewenangan untuk menciptakan dan menerapkan hukum. Berdasarkan pendapat dari beberapa ahli di atas dapat disimpulkan bahwa pada dasarnya hukum diberlakukan untuk masyarakat dengan tujuan untuk kesejahteraan masyarakat itu sendiri. Dapat disimpulkan unsur-unsur yang terkandung dalam 
hukum itu adalah peraturan-peraturan yang dibuat oleh yang berwenang, tujuannya mengatur dan menjaga tata tertib kehidupan masyarakat, mempunyai ciri memerintah dan melarang, bersifat memaksa agar ditaati, dan memberikan sangsi bagi yang melanggarnya.

Tujuan utama hukum adalah untuk mewujudkan ketertiban (order). Ketertiban merupakan syarat dasar bagi adanya satu masyarakat yang merupakan fakta dan kebutuhan objektif bagi setiap masyarakat. (Kusumaatmadja dalam Rasjidi, 1993:127). Gustav Radbruch (Marwan Mas, 2004:84-85) mengemukakan tiga nilai dasar tujuan hukum yang disebut asas prioritas yaitu keadilan, kemanfaatan, dan kepastian hukum. Dalam pelaksanaan hukum hendaknya memperhatikan substansi tujuan hukum dengan menempatkan urutan prioritas yang senantiasa didahulukan dalam setiap putusan ataupun kebijaksanaan hukum dari para pelaksananya. Muchsin (2002:84-93) mengatakan bahwa dalam penerapan hukum (rechtstoepassing) tergantung pada unsur hukum, unsur struktural, unsur masyarakat, dan unsur budaya yang merupakan kunci sukses sebuah penerapan hukum. Tidak jauh berbeda dengan pendapat Soekanto dalam Sunggono (1994:157-158) yang mengatakan bahwa dalam penerapan hukum diperlukan keserasian empat unsur yaitu peraturan hukum itu sendiri, mentalitas petugas yang menerapkan hukum, fasilitas, dan warga masyarakat sebagai objek. Namun keefektifan suatu peraturan hukum itu tergantung sekali pada dukungan-dukungan yang penuh dari nilai-nilai dan sikap-sikap masyarakat. Tujuan penegakan/penerapan hukum adalah compliance terhadap persyaratan-persyaratan perlindungan lingkungan yang biasa dituangkan dalam izin (license) baku mutu lingkungan dan peraturan perundang-undangan lainnya (Sentosa dalam Syahrin, 2003:207). Sistem penegakan hukum yang baik menyangkut penyerasian antara nilai-nilai dengan kaidah-kaidah serta perilaku nyata dari manusia karena manusialah yang menciptakan hukum itu dan sekaligus sebagai pelaksananya (Sunggono, 1994:156).

Peraturan Daerah tentang IMB mengikat seluruh warga masyarakat di daerah tersebut tanpa kecuali. Oleh karena itu, guna menjaga kewibawaan ruang, Perda sebagai peraturan perundang-undangan dan sekaligus untuk mewujudkan tertib tata ruang, perlu adanya sanksi pidana dan sanksi administratif yang tegas terhadap pelanggaran Undang-Undang tersebut. Hukum dapat berfungsi sebagai sarana penggerak perubahan masyarakat, sangat diharapkan bahwa pelaksanaan Undang-Undang No.26 Tahun 2007 tentang Penataan Ruang berikut peraturan pelaksanaannya mampu meningkatkan kesadaran masyarakat dalam mewujudkan tertib tata ruang, menuju pada terciptanya kondisi kesejahteraan masyarakat di segenap aspek kehidupan. Dalam pemberlakuan suatu kebijakan/peraturan tata ruang dan khususnya peraturan IMB, perlu adanya pembudayaan hukum sebagai hukum positif yang didasarkan pada pengertian bahwa peraturan tersebut diperlukan masyarakat untuk mengatur/menata dan mengendalikan ruang sebagai tempat aktivitas manusia. Dengan izin-izin yang telah diperoleh warga masyarakat, akan menjamin kepastian hukum dan sekaligus nilai tambah dari lahan dan atau bangunan yang dimilikinya. Hal ini juga merupakan kehendak Pemerintah dan masyarakat dalam rangka mewujudkan tertib tata ruang khususnya melalui IMB, sehingga IMB tersebut harus dapat menjadi kebutuhan masyarakat yang mengikat dan sekaligus ditaati sebagai kaidah hukum positif baik bagi para aparatur pemerintah maupun para warga masyarakat.

Penegakan/penerapan hukum sangat dipengaruhi oleh unsur-unsur hukum itu sendiri, masyarakat sebagai objek, institusi sebagai pelaksana dan diharapkan bahwa hukum itu dapat menciptakan kesejahteraan bagi masyarakat. Menurut Bachsan dalam Waluyo (2002:33), masyarakat dalam mengimplementasikan peraturan dipengaruhi oleh faktor ekstern dan faktor intern. Faktor ekstern adalah bersumber dari peraturan itu sendiri yang berupa asas dan 
fungsi dari peraturan, sedangkan faktor intern adalah faktor yang ada pada manusia sebagai masyarakat hukum yaitu faktor psikologi dan faktor rasional. Selain faktor intern yang timbul dari kesadaran subjek hukum, faktor ekstern yang tak kalah penting adalah upaya sosialisasi yang dilakukan oleh pihak pemerintah agar peraturan-peraturan berhasil guna. Dalam rangka mewujudkan efektifitas penataan ruang sesuai fungsinya diperlukan proses pembudayaan hukum. Faktor manusia yang menjadi objek dan sekaligus sebagai subjek peraturan dituntut untuk mempunyai tingkat kesadaran moral yang tinggi. Kesadaran moral masyarakat tidak mungkin akan timbul dengan sendirinya, akan tetapi akan berkembang melalui tahapan yang dimulai dari moral menuju kepada perwujudan sikap, tingkah laku, dan kepatuhan terhadap peraturan yang berlaku.

\section{KEDUDUKAN IMB DALAM PENGENDALIAN PEMANFAATAN RUANG}

Izin mendirikan bangunan, yang selanjutnya disingkat IMB, adalah perizinan yang diberikan oleh pemerintah daerah kepada pemohon untuk membangun baru, rehabilitasi/renovasi, dan/atau memugar dalam rangka melestarikan bangunan sesuai dengan persyaratan administratif dan persyaratan teknis yang berlaku (Permendagri No.32 tahun 2010). Izin Mendirikan Bangunan merupakan perizinan yang diberikan oleh Pemerintah Daerah kepada orang pribadi atau badan untuk mendirikan suatu bangunan yang dimaksudkan desain, pelaksanaan pembangunan dan bangunan sesuai dengan Rencana Tata Ruang yang berlaku, sesuai dengan Koefisien Dasar Bangunan (KDB), Koefisien Luas Bangunan (KLB), Koefisien Ketinggian Bangunan (KKB) yang ditetapkan dan sesuai dengan syarat-syarat keselamatan bagi yang menempati bangunan (Perda Kabupaten Tana Toraja No.3 Tahun 2009). Dasar pengaturan IMB adalah Undang-Undang Nomor 31 Tahun 2001 tentang Pajak dan Retribusi Daerah, yang kemudian dijabarkan masing-masing daerah dalam Peraturan Daerah. Demikian halnya Kabupaten Tana Toraja telah menyusun Perda No.3 Tahun 2009 tentang Retribusi IMB (merupakan penyempurnaan dari Perda No.11 Tahun 2002) dan kemudian memberikan wewenang kepada Dinas Permukiman dan Tata Ruang (DPTR) untuk menerbitkan IMB. Persyaratan lingkungan meliputi penentuan garis sempadan atau jarak maksimum bangunan terhadap batas jalan, jarak bebas muka samping dan belakang bangunan, batas-batas persil pembangunan dan jarak antar bangunan, keadaan tanah tempat bangunan, dan lain-lain. Sedangkan persyaratan bangunan antara lain meliputi luas denah bangunan, tinggi bangunan, ukuran-ukuran ruang, pencahayaan, dan pengudaraan.

Dari segi arsitektur, IMB juga berguna untuk mempertahankan nilai-nilai budaya warisan leluhur. Sebelum mendirikan suatu bangunan sudah menjadi ketentuan untuk segera melakukan pengurusan Izin Mendirikan Bangunan agar memiliki kepastian hukum atas kelayakan, kenyamanan, dan keamanan atas fungsi bangunan tersebut. IMB tidak hanya berlaku bagi pembangunan bangunan baru tetapi juga terhadap pembongkaran, renovasi, menambah, mengubah bentuk atau struktur bangunan. Dengan memiliki IMB, kepastian hukum menjadi jelas atas kepemilikan bangunan yang dibangun. Selain itu dengan memiliki IMB dapat lebih mudah dalam mengurus kredit bank dan izin usaha, transaksi jual-beli, dan sewa menyewa. Fungsi Izin Mendirikan Bangunan adalah sebagai alat pengendali penataan ruang dan sebagai jaminan kepastian hukum. Masyarakat dalam melakukan kegiatan membangun/menambah/merubah bangunan memerlukan jaminan adanya kepastian hukum. IMB yang dimiliki oleh masyarakat menjauhkan bangunannya dari status bangunan liar dan sekaligus mempermudah masyarakat ketika berkaitan dengan tanah dan bangunan karena memiliki nilai lebih yaitu IMB. 


\title{
ANALISIS KESESUAIAN PENGAJUAN DAN PELAKSANAAN IZIN MENDIRIKAN BANGUNAN (IMB) DI KECAMATAN MAKALE KABUPATEN TANA TORAJA
}

\begin{abstract}
Identifikasi Data Karakteristik Masyarakat
Pada proses identifikasi permohonan IMB yang dianalisis adalah karakteristik responden yaitu wilayah, tahun, usia, pekerjaan, pendidikan, pengeluaran, jumlah tanggungan, jenis bangunan, fungsi bangunan, letak bangunan. Dengan hasil analisis adalah sebagian besar masyarakat yang memiliki IMB adalah masyarakat dengan tingkat pendidikan yang tinggi (Sarjana). Sebagian besar masyarakat yang memiliki IMB juga merupakan masyarakat dengan tingkat ekonomi menengah dan tinggi. Kondisi bangunan yang memiliki IMB sebagian besar berupa bangunan permanen. Sebagian besar bangunan yang memiliki IMB berada di jalan kelurahan. Hal ini karena sebagian besar bangunan yang dimiliki responden merupakan bangunan rumah tinggal yang tentunya membutuhkan kenyamanan.
\end{abstract}

\section{Identifikasi Pemahaman Masyarakat Tentang IMB}

Pada tahap proses analisis pemahaman masyarakat dengan komponen variabel yang dianalisis adalah pengetahuan keharusan memiliki IMB, pengetahuan prosedur pengajuan IMB, pengetahuan KDB, GSB, GSS, pengetahuan mengenai RDTRK-Makale, pengetahuan tentang jenis pelanggaran, pemahaman tentang dasar memohon IMB, pemahaman tentang tujuan mengurus $\mathrm{IMB}$, pemahaman tentang manfaat $\mathrm{IMB}$, persepsi perlunya sanksi bagi yang melanggar IMB, sosialisasi, pelayanan pemerintah, biaya retribusi, pelaksanaan peninjauan oleh petugas, kenyamanan lingkungan sekitar, sikap mencontoh bangunan. Dan hasil yang diperoleh adalah umumnya responden telah mengetahui tentang IMB dan menyadari bahwa aturan-aturan yang berkaitan dengan IMB perlu untuk dilaksanakan dengan sebaik-baiknya. Masyarakat masih memiliki kecenderungan untuk mencontoh bangunan sekitar utamanya dalam hal pelaksanaan Garis Sempadan Bangunan. Hal ini dipicu pula oleh tidak adanya tindakan tegas dari pihak pemerintah daerah terhadap bangunan yang telah melanggar aturan IMB. Pemerintah dalam penyelenggaraan IMB telah berupaya untuk memberikan pelayanan yang sebaik-baiknya kepada masyarakat walaupun masyarakat beranggapan bahwa retribusi IMB yang berlaku adalah masih tergolong tinggi.

\section{Analisis Terhadap Ketidaksesuaian IMB Dengan Kondisi Eksisting Bangunan}

Tahap analisis ketidaksesuaian kondisi eksisting bangunan dengan permohonan (pengajuan) IMB adalah merupakan tahap analisis terhadap luas bangunan, fungsi bangunan, Koefisien Dasar Bangunan (KDB), Garis Sempadan Sungai (GSS), Garis Sempadan Bangunan (GSB). Berdasarkan hasil penelitian jenis ketidaksesuaian IMB yang terjadi dalam masyarakat adalah ketidaksesuaian terhadap Koefisien Dasar Bangunan (KDB), Garis Sempadan Bangunan (GSB), Fungsi Bangunan, Luas Bangunan dan Garis Sempadan Sungai (GSS). Ketidaksesuaian ini paling banyak terjadi di wilayah kelurahan Kamali Pentalluan. Berdasarkan RDTRK-Makale (2008-2017) Kelurahan Kamali Pentalluan terletak di BWK IV dan memiliki fungsi pelayanan tingkat regional yaitu terminal regional dan pasar regional (sebagai alternatif pemindahan Pasar Sentral Makale). Hal inilah yang menarik masyarakat untuk membeli lahan di sekitar Kelurahan Kamali Pentalluan karena melihat potensi Kelurahan Kamali Pentalluan yang akan berkembang di masa yang akan datang, disamping itu ketersediaan lahan yang relatif cukup luas.

Analisis Terhadap Faktor-Faktor yang Mempengaruhi Ketidaksesuaian Dalam Pelaksanaan IMB di Kecamatan Makale Kabupaten Tana Toraja

Untuk mengetahui faktor-faktor yang mempengaruhi ketidaksesuaian pelaksanaan IMB dilakukan dengan analisis faktor dengan mereduksi variable-variabel berdasarkan hasil jawaban kuesioner dari 104 responden. Variabel-variabel tersebut dianggap sebagai faktor-faktor yang 
ikut mempengaruhi masyarakat Kecamatan Makale dalam pelaksanaan IMB. Berdasarkan hasil analisis terdapat beberapa faktor yang mempengaruhi ketidaksesuaian pelaksanaan IMB yang kemudian dikelompokkan dalam 5 (lima) faktor yaitu Pengetahuan Masyarakat Mengenai IMB, Tingkat Kesadaran Masyarakat akan pentingnya IMB, Penanganan dan Kebijakan Pemerintah, Faktor Ekonomi, serta Kondisi Lingkungan Sekitar dan sikap Mencontoh Bangunan Sekitar.

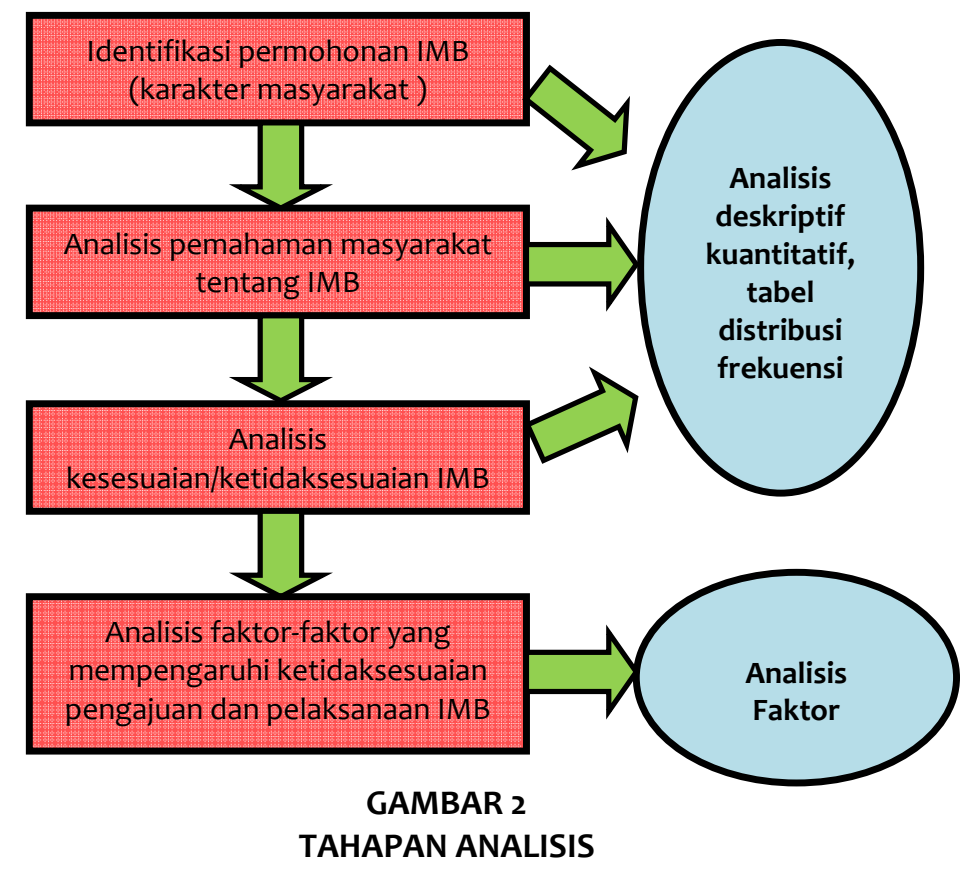

\section{KESIMPULAN}

Sebagian besar masyarakat Kecamatan Makale sudah mengetahui bahwa setiap bangunan seharusnya memiliki IMB. Hal ini dapat dilihat dari banyaknya masyarakat Kecamatan Makale yang sudah memiliki IMB untuk bangunannya. Dalam proses pelaksanaan IMB masih rendah dimana sebagian besar dari mereka belum memiliki pemahaman tentang arti pentingnya IMB tersebut. Rendahnya pemahaman masyarakat tersebut terlihat dari masih banyaknya terjadi pelanggaran IMB. Pemahaman masyarakat dalam pelaksanaan IMB bisa dilihat dari tingkat kesesuaian kondisi eksisting bangunan dengan dokumen IMB. Hasil penelitian menunjukkan bahwa terdapat beberapa jenis ketidaksesuaian terhadap IMB yaitu pelanggaran Koefisien Dasar Bangunan (KDB), Garis Sempadan Bangunan (GSB), Fungsi Bangunan, Luas Bangunan dan Garis Sempadan Sungai (GSS). Ketidaksesuaian ini paling banyak terjadi di wilayah Kelurahan Kamali Pentalluan. Berdasarkan RDTRK-Makale (2008-2017) Kelurahan Kamali Pentalluan terletak di BWK IV dan memiliki fungsi pelayanan tingkat regional yaitu terminal regional dan pasar regional (sebagai alternatif pemindahan Pasar Sentral Makale). Hal inilah yang menarik perhatian masyarakat untuk membeli lahan di sekitar Kelurahan Kamali Pentalluan karena melihat potensi Kelurahan Kamali Pentalluan yang akan berkembang dimasa yang akan datang, disamping itu ketersediaan lahan yang relatif cukup luas. Terdapat lima faktor yang mempengaruhi kesesuaian pengajuan dan pelaksanaan IMB di Kecamatan Makale yaitu pengetahuan masyarakat mengenai IMB, tingkat kesadaran masyarakat akan pentingnya IMB, penanganan dan kebijakan pemerintah, faktor ekonomi, serta kondisi lingkungan sekitar dan sikap mencontoh bangunan sekitar. 


\section{DAFTAR PUSTAKA}

Branch, Melville. 1995. Perencanaan Kota Komprehensif, Pengantar, dan Penjelasan. Yogyakarta: Gajah Mada University Press.

Budihardjo, Eko. Bandung. 1997. Tata Ruang Perkotaan. Bandung: P.T. Alumni

Chapin, F.S. dan Edward J. Kaiser. 1979. Urban Land Use Planning. London: University of Illinois Press.

Mas, Marwan. 2004. Pengantar Ilmu Hukum. Bogor: Ghalia Indonesia.

Muchsin dan Fadillah Putra. 2001. Hukum dan Kebijakan Publik. Surabaya: Universitas Sunangiri Surabaya dan Averroes Press.

Perda Kabupaten Tana Toraja No.1 Tahun 2003 tentang RTRWK.

Perda Kabupaten Tana Toraja No.2 Tahun 2009 tentang Penataan Bangunan.

Perda Kabupaten Tana Toraja No.3 Tahun 2009 tentang Retribusi IMB.

Peraturan Pemerintah No.15 Tahun 2010 tentang Penyelenggaraan Penataan Ruang.

Rencana Detail Tata Ruang Kawasan Perkotaan (RDTRK) Makale (2007-2017).

Sujarto, Djoko. 1989. Faktor Sejarah Perkembangan Kota Dalam Perencanaan Perkembangan Kota. Bandung: Fakultas Teknik Sipil dan Perencanaan ITB

Susanto, Yuniar Teguh, 2010. "Faktor-Faktor Pertimbangan Perizinan Dalam Pengendalian Pemanfaatan Ruang Di Kabupaten Pemalang." Tesis Tidak Diterbitkan, Program Studi Magister Pembangunan Wilayah dan Kota, Fakultas Teknik Universitas Diponegoro, Semarang.

Sunggono, Bambang. 1994. Hukum Dan Kebijakan Publik. Jakarta: Sinar Grafika.

Supriyatna, Budi. 2009. Manajemen Tata Ruang. Tangerang: Media Brilian.

Undang-Undang No.26 Tahun 2007 tentang Penataan Ruang.

Undang-Undang No.28 Tahun 2002 tentang Bangunan Gedung.

Undang-Undang No.28 Tahun 2008 tentang Pembentukan Kabupaten Toraja Utara.

Waluyo, Agus Cipto. 2002. "Partisipasi Masyarakat Terhadap Pelaksanaan Ijin Mendirikan Bangunan di Kota Kecamatan Colomadu Kabupaten Karanganyar." Tesis Tidak Diterbitkan, Program Studi Magister Pembangunan Wilayah Dan Kota, Fakultas Teknik Universitas Diponegoro, Semarang.

Yunus, Hadi Sabari. 1999. Struktur Ruang Kota. Yogyakarta: Pustaka Pelajar. 